\title{
PENGARUH PENDAPATAN ASLI DAERAH, DANA ALOKASI UMUM DAN DANA ALOKASI KHUSUS TERHADAP TINGKAT KEMANDIRIAN KEUANGAN DAERAH KABUPATEN SUMBAWA PERIODE TAHUN ANGGARAN 2012 - 2018
}

\section{Siti Aisyah}

\author{
Fakultas Ekonomi dan Bisnis Universitas Teknologi Sumbawa \\ email: aisyuuh27@gmail.com/ telp: +62 01296084590
}

\begin{abstract}
Abstrak: Otonomi daerah adalah kewenangan daerah otonom untuk mengatur dan mengurus kepentingan masyarakat setempat menurut prakarsa sendiri berdasarkan aspirasi masyarakat sesuai dengan peraturan perundang-undangan. Otonomi daerah bertujuan untuk mewujudkan kemandirian daerah sehingga daerah bebas untuk mengatur dirinya tanpa ada campur tangan pemerintah pusat. Penelitian ini bertujuan untuk mengetahui pengaruh pendapatan asli daerah, dana alokasi umum dan dana alokasi khusus terhadap kemandirian keuangan daerah. Data yang digunakan dalam penelitian ini berupa data kuantitatif yang bersumber dari Badan Pusat Statistik (BPS) Sumbawa. Teknik analisis data dalam penelitian ini menggunakan analisis regresi linier berganda. Hasil penelitian menunjukkan pendapatan asli daerah berpengaruh positif signifikan terhadap kemandirian keuangan daerah, dana alokasi umum tidak berpengaruh terhadap kemandirian keuangan daerah, dan dana alokasi khusus berpengaruh negatif terhadap kemandirian keuangan daerah.
\end{abstract}

\section{Kata Kunci : Kemandirian keuangan daerah, Pendapatan asli daerah, Dana alokasi umum, Dana alokasi khusus.}

\begin{abstract}
Regional autonomy is the authority of the autonomous region to regulate and manage the interests of the local community according to the initiative itself based on the aspirations of the community in accordance with the laws and regulations. Regional autonomy aims to realize regional independence so that the regions are free to regulate themselves without any interference from the central government. This study aims to determine the effect of local revenue, general allocation funds and special allocation funds for regional financial independence. The data used in this study are quantitative data sourced from the Sumbawa Central Statistics Agency (BPS). Data analysis techniques in this study used the multiple linear regression analysis. The results of the study show that local revenue has a significant positive effect on regional
\end{abstract}


financial independence, general allocation funds have no effect on regional financial independence, and special allocation funds have a negative effect on regional financial independence.

\section{Keywords : Regional financial independence, Regional original income, General allocation funds, Special allocation funds.}

\section{PENDAHULUAN}

Otonomi daerah adalah kewenangan daerah otonom untuk mengatur dan mengurus kepentingan masyarakat setempat menurut prakarsa sendiri berdasarkan aspirasi masyarakat sesuai dengan peraturan perundang-undangan (Suparmoko, 2002). Otonomi daerah bertujuan untuk mewujudkan kemandirian daerah sehingga daerah bebas untuk mengatur dirinya tanpa ada campur tangan pemerintah pusat. Dalam melaksanakan pembangunan dan pembiayaan daerah, pemerintah daerah haruslah memiliki dana yang bersumber dari pendapatanpendapatan yang diterima daerah. Undang-undang Republik Indonesia No. 33 Tahun 2004, menyatakan pendapatan daerah dikelompokan menjadi 3 yaitu: (1) Pendapatan Asli Daerah (PAD), (2) Dana Perimbangan, dan (3) Lain-lain penerimaan yang sah. Pendapatan Asli Daerah (PAD) merupakan semua penerimaan daerah yang berasal dari sumber ekonomi asli daerah (Halim, 2007). Sedangkan dana perimbangan adalah dana yang bersumber dari penerimaan Anggaran Pendapatan dan Belanja Negara (APBN), yang dialokasikan kepada daerah untuk membiayai kebutuhan daerah dalam rangka pelaksanaan desentralisasi (Kuncoro, 2010). Kemudian Lain-lain pendapatan menurut Undang-undang No. 33 Tahun 2004 yaitu terdiri atas pendapatan hibah yang merupakan bantuan tidak mengikat dan Dana Darurat yang berasal dari APBN.

Halim (2013) menyatakan bahwa pengelolaan keuangan daerah yang transparan, jujur, demokratis, efektif, efisien, dan akuntabel, salah satunya dengan menggunakan rasio kemandirian keuangan daerah. Undang-Undang No. 23 tahun 2014 menyatakan kemandirian keuangan daerah berarti pemerintah dapat melakukan pembiayaan dan pertanggungjawaban keuangan sendiri, melaksanakan sendiri dalam rangka asas desentralisasi.

Kemandirian keuangan daerah ditunjukkan oleh besar kecilnya pendapatan asli daerah (PAD) dibandingkan dengan pendapatan daerah yang berasal dari sumber lain seperti bantuan pemerintah pusat ataupun dari pinjaman (Halim, 2007). Menurut 
hasil penelitian Muliana (2009) semakin besar PAD dibandingkan dengan bantuan pemerintah pusat dan pinjaman maka Pemerintah Kabupaten/Kota tersebut dikatakan mandiri. Dengan begitu PAD merupakan hal yang utama dalam mengukur tingkat kemandirian keuangan daerah yang memang benar-benar digali dari daerah itu sendiri sehingga dapat mencerminkan kondisi riil daerah, sementara Dana Perimbangan dan Lain-lain Pendapatan dari Pemerintah Pusat semestinya hanya bersifat pendukung bagi pelaksanaan pemerintahan dan pembangunan daerah.

Dalam kenyataannya pemerintah daerah belum dapat sepenuhnya lepas dari pemerintah pusat dalam mengatur rumah tangga daerah, yang ditunjukkan dengan adanya ketergantungan yang lebih besar kepada bantuan pemerintah diantaranya Dana Alokasi Umum dan Dana Alokasi Khusus.

Dalam hal ini, pemerintah daerah Kabupaten Sumbawa masih menerima DAU dan DAK dalam jumlah yang lebih besar daripada pendapatan asli pemerintah daerah Kabupaten Sumbawa sendiri. Hal ini terlihat dalam tabel 1.1. Pokok bahasan dalam penelitian ini yaitu mengetahui faktor-faktor penyebab tinggi rendahnya tingkat kemandirian keuangan daerah kabupaten Sumbawa dengan variabel Pendapatan Asli Daerah (PAD), Dana Alokasi Umum (DAU) dan Dana Alokasi Khusus (DAK) periode tahun anggaran $2012-2018$.

Tabel 1.1

Penerimaan Daerah Kabupaten Sumbawa Tahun 2012 - 2018 (dalam Rupiah)

\begin{tabular}{|c|c|c|c|c|}
\hline Tahun & PAD & DAU & DAK & TPD \\
\hline 2018 & 145.212 .584 .267 & 821.927 .598 .000 & 333.839 .050 .000 & 1.632 .004 .948 .475 \\
\hline 2017 & 248.865 .991 .559 & 815.888 .480 .000 & 355.315 .140 .000 & 1.590 .214 .773 .021 \\
\hline 2016 & 144.594 .755 .964 & 740.068 .845 .248 & 332.576 .447 .850 & 1.532 .348 .649 .842 \\
\hline 2015 & 136.157 .191 .775 & 757.530 .420 .000 & 120.471 .410 .000 & 1.244 .513 .915 .604 \\
\hline 2014 & 86.017 .330 .945 & 724.963 .659 .000 & 81.244 .790 .000 & 1.141 .445 .044 .840 \\
\hline 2013 & 73.069 .462 .998 & 647.640 .513 .000 & 79.836 .780 .000 & 974.265 .950 .878 \\
\hline 2012 & 66.755 .174 .020 & 586.148 .017 .000 & 63.238 .890 .000 & 856.858 .021 .196 \\
\hline
\end{tabular}

Sumber: sumbawakab.bps.go.id diolah, 2019.

Rumusan masalah dalam penelitian ini adalah mengetahui bagaimana pengaruh Pendapatan Asli Daerah, Dana Alokasi Umum dan Dana Alokasi Khusus terhadap Tingkat Kemandirian Keuangan Daerah Kabupaten Sumbawa tahun anggaran 2012 2018 baik secara parsial (masing-masing) maupun secara simultan (bersama-sama). 


\section{Rumusan Hipotesis}

$\left(\mathrm{H}_{1}\right)$ : Pendapatan Asli Daerah berpengaruh positif signifikan terhadap tingkat kemandirian keuangan daerah Kabupaten Sumbawa

$\left(\mathrm{H}_{2}\right)$ : Dana Alokasi Umum berpengaruh negatif signifikan terhadap tingkat kemandirian keuangan daerah Kabupaten Sumbawa

$\left(\mathrm{H}_{3}\right)$ : Dana Alokasi Khusus berpengaruh negatif signifikan terhadap tingkat kemandirian keuangan daerah Kabupaten Sumbawa

$\left(\mathrm{H}_{4}\right)$ : Pendapatan Asli Daerah, Dana Alokasi Umum dan Dana Alokasi Khusus berpengaruh signifikan terhadap tingkat kemandirian keuangan daerah Kabupaten Sumbawa

\section{METODE PENELITIAN}

Jenis penelitian yang digunakan dalam penelitian ini adalah jenis penelitian kuantitatif deskriptif. Jenis data yang digunakan adalah data kuantitatif yaitu data berupa angka-angka, dan sumber data yang digunakan merupakan data sekunder yang diperoleh dari Badan Pusat Statistik (BPS) Sumbawa, Peraturan Daerah (Perda) Kabupaten Sumbawa, dan data atau informasi lainnya yang terkait dengan penelitian ini dengan menggunakan teknik dokumentasi dan studi pustaka.

\section{Uji Asumsi Klasik}

Sebelum melakukan pengujian regresi, terlebih dahulu dilakukan pengujian asumsi klasik yang berguna untuk mengetahui apakah data yang digunakan telah memenuhi ketentuan dalam model regresi. Pengujian yang dilakukan antara lain Uji Normalitas Data, Uji Multikolinearitas, Uji Heteroskedastisitas, dan Uji Autokorelasi.

\section{Uji Regresi Berganda}

Analisis regresi linier berganda digunakan oleh peneliti, bila peneliti bermaksud meramalkan bagaimana keadaan (naik turunnya) variabel dependen, bila dua atau lebih variabel independen sebagai faktor prediktor dimanipulasi (dinaik turunkan nilainya) (Sugiyono, 2011). Dalam penelitian ini variabel independen yang digunakan dalam penelitian ini adalah Pendapatan Asli Daerah, Dana Alokasi Umum dan Dana Alokasi 
Khusus, sedangkan variabel dependen dalam penelitian ini adalah kemandirian keuangan daerah.

\section{Uji Koefisien Determinasi $\left(\mathbf{R}^{2}\right)$}

Menurut Ghozali (2012) koefisien determinasi $\left(\mathrm{R}^{2}\right)$ merupakan alat untuk mengukur seberapa jauh kemampuan model dalam menerangkan variasi variabel dependen.

\section{Uji Hipotesis}

Uji Statistik t (Parsial)

Uji $t$ digunakan untuk menunjukkan seberapa jauh pengaruh satu variabel bebas/independen secara individual dalam menerangkan variasi variabel dependen (Ghozali, 2012). Dasar pengambilan keputusan digunakan dalam uji $t$ adalah sebagai berikut:

1) Jika nilai probabilitas signifikansi $>0,05$, maka hipotesis ditolak. Hipotesis ditolak mempunyai arti bahwa variabel independen tidak berpengaruh signifikan terhadap variabel dependen.

2) Jika nilai probabilitas signifikansi < 0,05, maka hipotesis diterima. Hipotesis diterima mempunyai arti bahwa variabel independen berpengaruh signifikan terhadap variabel dependen.

Uji Statistik F (Simultan)

Menurut Ghozali (2012) Uji Statistik F pada dasarnya menunjukkan apakah semua variabel independen atau variabel bebas yang dimasukkan dalam model mempunyai pengaruh secara bersama-sama (simultan) terhadap variabel independen atau variabel terikat. Untuk menguji hipotesis ini digunakan statistik $\mathrm{F}$ dengan kriteria pengambilan keputusan sebagai berikut:

1) Jika nilai $F_{\text {hitung }}$ lebih kecil dari $F_{\text {tabel }}$ maka hipotesis ditolak.

2) Jika nilai $F_{\text {hitung }}$ lebih besar dari $F_{\text {tabel }}$ maka hipotesis diterima.

\section{HASIL DAN PEMBAHASAN}

\section{Uji Asumsi Klasik}

Uji Normalitas Data 
Tabel Hasil Uji Normalitas

One-Sample Kolmogorov-Smirnov Test

\begin{tabular}{|ll|r|}
\hline & & \multicolumn{2}{|c|}{$\begin{array}{l}\text { Unstandardized } \\
\text { Residual }\end{array}$} \\
\hline Normal Parameters & a & Mean \\
& Std. Deviation & .0000000 \\
Most Extreme & Absolute & 3.26294684 \\
Differences & Positive & .202 \\
& Negative & .202 \\
Kolmogorov-Smirnov Z & &. .148 \\
Asymp. Sig. (2-tailed) & & .536 \\
a. Test distribution is Normal. & .937 \\
\hline
\end{tabular}

Sumber: data sekunder, diolah 2019.

Dari hasil pengujian di atas adalah nilai One-Sample Test Kolmogorov-Smirnov adalah sebesar 0,536 dengan nilai signifikansi $0,937>0,05$, sehingga data yang digunakan dalam penelitian ini dinyatakan berdistribusi normal.

Uji Multikolinieritas

Tabel Hasil Uji Multikolinearitas

\begin{tabular}{|ll|r|c|}
\hline \multirow{2}{*}{ Model } & \multicolumn{2}{|c|}{ Collinearity Statistics } \\
\cline { 2 - 4 } & Tolerance & \multicolumn{1}{c|}{ VIF } \\
\hline 1 & (Constant) & & \\
Pad & .260 & 3.846 \\
Dau & .319 & 3.134 \\
Dak & .286 & 3.498 \\
\hline
\end{tabular}

Sumber: data sekunder, diolah 2019.

Dalam tabel di atas diperoleh nilai VIF untuk masing-masing variabel bebas kurang dari 10 dan tolerance value berada diatas 0,10 . Hal ini menunjukkan tidak adanya korelasi antara sesama variabel bebas dalam model regresi dan disimpulkan tidak terdapat masalah multikolinieritas diantara sesama variabel bebas dalam model regresi yang dibentuk.

Uji Heteroskedastisitas

Tabel Hasil Uji Heteroskedastisitas 


\begin{tabular}{|ll|l|l|}
\hline \multicolumn{2}{|c|}{ Model } & \multicolumn{1}{|c|}{$\mathrm{T}$} & \multicolumn{1}{c|}{ Sig. } \\
\hline $1 \quad$ (Constant) & -.265 & .808 \\
& Pad & .936 & .418 \\
Dau & .575 & .606 \\
& Dak & -1.802 & .169 \\
\hline
\end{tabular}

Sumber: data sekunder, diolah 2019.

Berdasarkan tabel dapat dilihat bahwa hasil perhitungan dari masing-masing variabel menunjukkan bahwa nilai signifikansi masing-masing variabel $>0,05$. Sehingga dapat disimpulkan bahwa penelitian ini bebas dari gejala Heterokedastisitas dan layak digunakan dalam analisis regresi berganda.

Uji Autokorelasi

Tabel Hasil Uji Autokorelasi

Model Summaryb

\begin{tabular}{|l|c|r|r|r|r|}
\hline Model & $\mathrm{R}$ & $\begin{array}{c}\mathrm{R} \\
\text { Square }\end{array}$ & $\begin{array}{c}\text { Adjusted } \\
\text { R Square }\end{array}$ & $\begin{array}{c}\text { Std. Error of } \\
\text { the Estimate }\end{array}$ & $\begin{array}{c}\text { Durbin- } \\
\text { Watson }\end{array}$ \\
\hline 1 & $.996 \mathrm{a}$ & .991 & .983 & 4.61450 & 2.050 \\
\hline
\end{tabular}

Sumber: data sekunder, diolah 2019.

Berdasarkan tabel di atas, dapat dilihat bahwa nilai $U j i$ Durbin-Watson adalah 2,050. Dengan $\mathrm{k}=3$ dan $\mathrm{n}=7$ dihasilkan nilai dU adalah 1,8964 . Pengambilan keputusan yang menyatakan tidak adanya masalah autokorelasi yaitu, jika dU $<\mathrm{dW}<(4-\mathrm{dU})$. Pada penelitian ini dihasilkan 1,8964 $<2,050<2,103$, sehingga dapat dinyatakan bahwa pada model regresi tidak terdapat masalah autokorelasi.

\section{Analisis Regresi Berganda}

Tabel Hasil Analisis Regresi Berganda

\begin{tabular}{|c|c|c|c|c|c|c|}
\hline \multirow{2}{*}{\multicolumn{2}{|c|}{ Model }} & \multicolumn{2}{|c|}{$\begin{array}{c}\text { Unstandardized } \\
\text { Coefficients }\end{array}$} & \multirow{2}{*}{\begin{tabular}{|c|}
$\begin{array}{c}\text { Standardized } \\
\text { Coefficients }\end{array}$ \\
Beta \\
\end{tabular}} & \multirow[b]{2}{*}{$\mathrm{T}$} & \multirow[b]{2}{*}{ Sig. } \\
\hline & & B & $\begin{array}{l}\text { Std. } \\
\text { Error }\end{array}$ & & & \\
\hline \multirow[t]{3}{*}{1} & (Constant) & 56.750 & 23.558 & & 2.409 & .095 \\
\hline & pad (x1) & .741 & .059 & 1.320 & 12.630 & .001 \\
\hline & dau (x2) & -.013 & .039 & -.031 & -.326 & .766 \\
\hline
\end{tabular}




\begin{tabular}{|c|c|c|c|c|c|}
\hline $\operatorname{dak}(x 3)$ & -.103 & .026 & -.399 & -4.006 & .028 \\
\hline
\end{tabular}

a. Dependent Variable: kmd (y)

Berdasarkan hasil perhitungan tabel Coefficients ${ }^{2}$ dapat dilihat bahwa konstanta sebesar 56,75 dan koefisien regresi masing-masing sebesar pendapatan asli daerah 0,741; dana alokasi umum -0,013; dan dana alokasi khusus -0,103 sehingga hasil tersebut dapat dibuat persaman regresi sebagai berikut:

$$
\begin{aligned}
\mathrm{Y} & =\mathrm{a}+\mathrm{b}_{1} \mathrm{X}_{1}+\mathrm{b}_{2} \mathrm{X}_{2}+\mathrm{b}_{3} \mathrm{X}_{3}+\mathrm{e} \\
& =56,75+0,741 \mathrm{X}_{1}-0,013 \mathrm{X}_{2}-0,103 \mathrm{X}_{3}+\mathrm{e}
\end{aligned}
$$

Berdasarkan persamaan yang telah dibuat dapat diketahui:

1) Nilai konstanta 56,75 berarti bahwa jika seluruh variabel independen yaitu pendapatan asli daerah, dana alokasi umum dan dana alokasi khusus dianggap konstan maka variabel dependen yaitu kemandirian keuangan daerah akan tetap bernilai 56,75 .

2) Nilai koefisien regresi pendapatan asli daerah sebesar 0,741 , hal ini berarti jika terjadi kenaikan 1 poin pendapatan asli daerah maka nilai kemandirian keuangan daerah bertambah sebesar 0,741 dengan asumsi bahwa variabel independen yang lain dari model regresi adalah tetap.

3) Nilai koefisien regresi dana alokasi umum sebesar -0,013, hal ini berarti jika terjadi kenaikan 1 poin dana alokasi umum maka nilai kemandirian keuangan daerah berkurang sebanyak 0,013 dengan asumsi bahwa variabel independen yang lain dari model regresi adalah tetap.

4) Nilai koefisien regresi dana alokasi khusus sebesar -0,103, hal ini berarti jika terjadi kenaikan 1 poin dana alokasi umum maka nilai kemandirian keuangan daerah berkurang sebanyak 0,103 dengan asumsi bahwa variabel independen yang lain dari model regresi adalah tetap.

\section{Koefisien Determinasi $\left(\mathbf{R}^{2}\right)$}

Tabel Hasil Uji Koefisien Determinasi

\begin{tabular}{|l|c|r|r|c|}
\multicolumn{7}{c|}{ Model Summary } \\
\hline Model & $\mathrm{R}$ & $\begin{array}{c}\mathrm{R} \\
\text { Square }\end{array}$ & $\begin{array}{c}\text { Adjusted R } \\
\text { Square }\end{array}$ & $\begin{array}{c}\text { Std. Error of the } \\
\text { Estimate }\end{array}$ \\
\hline 1 & $.996 \mathrm{a}$ & .991 & .983 & 4.61450 \\
\hline
\end{tabular}

a. Predictors: (Constant), dak (x3), dau (x2), pad (x1) 
Berdasarkan tabel Model Summary di atas dapat dilihat bahwa nilai koefisien determinasi $\left(R^{2}\right)$ sebesar 0,991 . Nilai ini menunjukkan bahwa tingkat kemandirian keuangan daerah di Kabupaten Sumbawa tahun anggaran 2012-2018 dipengaruhi oleh pendapatan asli daerah, dana alokasi umum dana dana alokasi khusus sebesar 99,1\% sedangkan 0,9\% dipengaruhi oleh variabel lainnya yang tidak diteliti dalam penelitian ini.

\section{Uji Hipotesis}

Uji Statistik t (Parsial)

\section{Tabel Hasil Uji Statistik t}

\begin{tabular}{|c|c|c|c|c|c|c|}
\hline \multicolumn{7}{|c|}{ Coefficients $^{\mathrm{a}}$} \\
\hline & \multirow[b]{2}{*}{ Model } & \multicolumn{2}{|c|}{$\begin{array}{c}\text { Unstandardized } \\
\text { Coefficients }\end{array}$} & \multirow{2}{*}{\begin{tabular}{|c|}
$\begin{array}{c}\text { Standardized } \\
\text { Coefficients }\end{array}$ \\
Beta
\end{tabular}} & \multirow[b]{2}{*}{$\mathrm{T}$} & \multirow[b]{2}{*}{ Sig. } \\
\hline & & B & $\begin{array}{l}\text { Std. } \\
\text { Error }\end{array}$ & & & \\
\hline \multirow[t]{4}{*}{1} & (Constant) & 56.750 & 23.558 & & 2.409 & .095 \\
\hline & pad $(x 1)$ & .741 & .059 & 1.320 & 12.630 & .001 \\
\hline & dau (x2) & -.013 & .039 & -.031 & -.326 & .766 \\
\hline & $\operatorname{dak}(x 3)$ & -.103 & .026 & -399 & -4.006 & .028 \\
\hline
\end{tabular}

a. Dependent Variable: kmd (y)

Uji $t$ digunakan untuk menguji hipotesis pertama yang diajukan dalam penelitian ini. Berdasarkan tabel Coefficients ${ }^{2}$ di atas, berikut adalah hasil uji hipotesis tersebut:

1. Pengaruh Pendapatan Asli Daerah dengan Tingkat Kemandirian Keuangan Daerah

Besarnya thitung variabel $\mathrm{X}_{1}$ terhadap variabel $\mathrm{Y}$ adalah sebesar 12,63 dimana thitung $>t_{\text {tabel }}(12,63>2,132)$. Hasil olahan menujukkan nilai signifikansi sebesar 0,001 $<0,05$. Berdasarkan perhitungan tersebut disimpulkan bahwa $\mathrm{H}_{0}$ ditolak dan $\mathrm{H}_{1}$ diterima, yang artinya variabel $\mathrm{X}_{1}$ yaitu Pendapatan Asli Daerah berpengaruh positif dan signifikan secara parsial terhadap kemandirian keuangan daerah.

Hasil penelitian ini menunjukkan bahwa Pendapatan Asli Daerah (PAD) berpengaruh positif dan signifikan terhadap tingkat kemandirian keuangan daerah. Hasil penelitian ini sejalan dengan hasil penelitian yang dilakukan oleh Marizka (2013), Yulianto (2018) dan Muliana (2009) yang menyatakan 
bahwa semakin meningkatnya Pendapatan Asli Daerah maka tingkat kemandirian keuangan daerah juga meningkat, dan sebaliknya semakin rendah Pendapatan Asli Daerah maka tingkat kemandirian keuangan daerah semakin rendah.

Dalam pelaksanaan otonomi daerah, sumber keuangan yang berasal dari pendapatan asli daerah lebih penting dibandingkan dengan pendapatan lain yang bersumber bukan dari daerah, karena pendapatan asli daerah merupakan sumber keuangan yang digali dalam wilayah daerah yang bersangkutan sehingga optimalisasi sumber-sumber pendapatan asli daerah perlu dilakukan untuk meningkatkan kemampuan keuangan daerah.

2. Pengaruh Dana Alokasi Umum dengan Tingkat Kemandirian Keuangan Daerah

Besarnya thitung variabel $\mathrm{X}_{2}$ terhadap variabel $\mathrm{Y}$ adalah sebesar 0,326 dengan tanda negatif. Hal tersebut berarti bahwa $t_{\text {hitung }}<t_{\text {tabel }}(0,326<2,132)$. Nilai signifikansinya 0,766 $>0,05$. Berdasarkan perhitungan tersebut disimpulkan bahwa $\mathrm{H}_{0}$ diterima dan $\mathrm{H}_{2}$ ditolak, yang artinya variabel $\mathrm{X}_{2}$ yaitu Dana Alokasi Umum berpengaruh negatif tetapi tidak signifikan secara parsial terhadap kemandirian keuangan daerah.

Hasil penelitian ini menunjukkan Dana Alokasi Umum (DAU) berpengaruh negatif tidak signifikan terhadap kemandirian keuangan daerah terbukti secara statistik. Artinya data yang dikumpulkan tidak berhasil membuktikan keterkaitan antara $\mathrm{X}$ dan $\mathrm{Y}$, dan bukan berarti $\mathrm{X}$ tidak berpengaruh terhadap Y melainkan data sampel tidak berhasil membuktikan hubungan tersebut. Hasil ini mendukung penelitian yang dilakukan oleh Marizka (2013) dan Yulianto (2018) yang menemukan secara parsial dana alokasi umum tidak berpengaruh signifikan terhadap kemandirian keuangan daerah.

Penggunaan dana alokasi umum yang dialokasikan oleh pemerintah pusat belum digunakan dan dimanfaatkan secara efektif dan efisien oleh pemerintah daerah berarti penggunaan dana tersebut belum mencapai target atau tujuan kepentingan publik serta penggunaanya belum untuk menghasilkan output yang maksimal atau berdaya guna. Hal ini terlihat dengan masih rendahnya rata-rata pendapatan asli daerah pada Kabupaten Sumbawa yaitu sebesar 9,68\%, sementara itu ratarata dana alokasi umum tinggi yaitu sebesar 58,46\%. Hal ini 
mengindikasikan bahwa penggunaan dana alokasi umum yang ditransfer oleh pemerintah pusat kepada daerah belum dimanfaatkan untuk sektor-sektor produktif yang dapat memberikan kontribusi yang besar kepada pendapatan asli daerah, oleh sebab itu dana alokasi umum tidak mempunyai pengaruh yang signifikan terhadap tingkat kemandirian keuangan daerah.

3. Pengaruh Dana Alokasi Khusus dengan Tingkat Kemandirian Keuangan Daerah

Besarnya $t_{\text {hitung }}$ variabel $\mathrm{X}_{3}$ terhadap variabel $\mathrm{Y}$ adalah sebesar 4,006 dengan tanda negatif. Hal tersebut berarti bahwa thitung $>t_{\text {tabel }}(4,006>2,132)$. Nilai signifikansinya 0,028 $<0,05$. Berdasarkan perhitungan tersebut disimpulkan bahwa $\mathrm{H}_{0}$ ditolak dan $\mathrm{H}_{3}$ diterima, yang artinya variabel $\mathrm{X}_{3}$ yaitu Dana Alokasi Khusus berpengaruh negatif dan signifikan secara parsial terhadap kemandirian keuangan daerah.

Hasil penelitian ini menunjukkan Dana Alokasi Khusus (DAK) berpengaruh negatif dan signifikan terhadap kemandirian keuangan daerah, hal ini sejalan dengan semua penelitian sebelumnya yakni Marizka (2013), Ikasari (2015), Yulianto (2018) dan Muliana (2009) yang mengatakan semakin besar dana alokasi khusus yang diterima oleh daerah maka kemandirian keuangan daerah semakin rendah, sebaliknya semakin kecil dana alokasi khusus yang diterima daerah maka kemandirian keuangan daerah semakin besar. Penerimaan dana alokasi khusus yang besar disebabkan oleh kemampuan pembiayaan daerah yang berasal dari pendapatan asli daerah masih rendah. Dana alokasi khusus dialokasikan kepada daerah tertentu untuk mendanai kegiatan khusus yang merupakan bagian dari program yang menjadi prioritas nasional yang menjadi urusan daerah serta untuk membantu daerah untuk mendanai kebutuhan fisik sarana dan prasarana dasar yang merupakan prioritas nasional di bidang pendidikan, kesehatan, infrastruktur, kelautan dan perikanan, pertanian, prasarana pemerintahan daerah serta lingkungan hidup.

Uji Statistik F (Simultan)

\section{Tabel Hasil Uji Statistik F}

ANOVAb 


\begin{tabular}{|ll|r|r|c|c|c|}
\hline \multicolumn{1}{|c|}{ Model } & Sum of Squares & Df & $\begin{array}{c}\text { Mean } \\
\text { Square }\end{array}$ & F & Sig. \\
\hline $1 \quad$ Regression & 7430.976 & 3 & 2476.992 & 116.325 & $.001 \mathrm{a}$ \\
& Residual & 63.881 & 3 & 21.294 & & \\
Total & 7494.857 & 6 & & & \\
\hline
\end{tabular}

a. Predictors: (Constant), dak (x3), dau (x2), pad (x1)

b. Dependent Variable:

kmd (y)

Uji $F$ digunakan untuk mengetahui pengaruh variabelvariabel independen secara bersama-sama terhadap variabel terikat. Berdasarkan tabel ANOVA ${ }^{2}$ nilai $F_{\text {hitung }}$ yang diperoleh dari model regresi adalah sebesar 116,325 dengan nilai probabilitas sebesar 0,001. Dengan menggunakan $a=5 \%$ maka diperoleh nilai $F_{\text {tabel }}$ sebesar 9,28, maka $F_{\text {hitung }}$ lebih besar dari $F_{\text {tabel }}$ yaitu $116,325>9,28$. Dan nilai signifikansinya lebih kecil dari a, yaitu $0,001<0,05$. Dengan demikian $\mathrm{H}_{0}$ ditolak dan $\mathrm{H}_{4}$ diterima, artinya bahwa variabel-variabel independen secara bersama-sama yaitu Pendapatan Asli Daerah (PAD), Dana Alokasi Umum (DAU) dan Dana Alokasi Khusus (DAK) berpengaruh signifikan terhadap tingkat kemandirian keuangan daerah di Kabupaten Sumbawa.

Hasil penelitian ini sejalan dengan hipotesis yang telah dirumuskan yakni menunjukkan bahwa Pendapatan Asli Daerah (PAD), Dana Alokasi Umum (DAU) dan Dana Alokasi Khusus (DAK) berpengaruh signifikan secara bersama-sama terhadap tingkat kemandirian keuangan daerah. Hal tersebut menunjukkan setiap pendapatan dan penerimaan daerah yang diterima dari Pendapatan Asli Daerah, Dana Alokasi Umum dan Dana Alokasi Khusus secara langsung berkontribusi dalam membantu kegiatan pelaksanaan pembangunan dan pelayanan kepada masyarakat, sehingga sangat mempengaruhi kondisi kemandirian keuangan daerah Sumbawa.

\section{PENUTUP}

\section{Kesimpulan}

Penelitian ini bertujuan untuk mengetahui pengaruh Pendapatan Asli Daerah, Dana Alokasi Umum dan Dana Alokasi Khusus terhadap kemandirian keuangan daerah Kabupaten Sumbawa tahun anggaran 2012 - 2018. Berdasarkan analisis data 
dan pengujian data dalam penelitian ini, dapat ditarik kesimpulan sebagai berikut:

1. Pendapatan Asli Daerah (PAD) berpengaruh positif signifikan terhadap kemandirian keuangan daerah Kabupaten Sumbawa.

2. Dana Alokasi Umum (DAU) berpengaruh negatif tidak signifikan terhadap keamandirian keuangan daerah Kabupaten Sumbawa.

3. Dana Alokasi Khusus (DAK) berpengaruh negatif dan signifikan terhadap kemandirian keuangan daerah Kabupaten Sumbawa.

4. Pendapatan Asli Daerah, Dana Alokasi Umum dan Dana Alokasi Khusus berpengaruh signifikan terhadap tingkat kemandirian keuangan daerah Kabupaten Sumbawa.

\section{Saran}

Berdasarkan hasil penelitian ini terdapat beberapa saran untuk perbaikan penelitian kedepannya, yakni sebagai berikut:

1. Disarankan untuk menambah atau mengganti dengan variabel lain yang tidak diikutsertakan dalam penelitian ini.

2. Mengganti pengukuran rasio kemandirian daerah dengan rasio kinerja keuangan pemerintah daerah, rasio efisiensi dan efektivitas dan lain sebagainya.

3. Menambah jumlah sampel dan rentang periode penelitian.

4. Menambah sumber-sumber informasi dan data terkait pengungkapan laporan semisal realisasi APBD yang teruptodate yang berupa laporan fisik pada daerah-daerah yang diteliti.

\section{DAFTAR PUSTAKA}

Apriana, Dina. dan Suryanto, Rudi., 2010. Analisis Hubungan Antara Belanja Modal, Pendapatan Asli Daerah, Kemandirian Daerah dan Pertumbuhan Ekonomi Daerah (Studi pada Kabupaten dan Kota se Jawa-Bali). Jurnal Akuntansi dan lnvestasi, Vol.XI No. 1, Januari.

Ghozali, Imam. 2012. Aplikasi Analisis Multivariate dengan Program IBM SPSS 20. Semarang: Badan Penerbit Universitas Diponegoro.

Halim, Abdul. 2002. Akuntansi Sektor Publik : Akuntabilitas Keuangan Daerah. Jakarta: Penerbit Salemba Empat.

Abdul. 2007. Akuntansi Sektor Publik Keuangan Daerah, edisi Revisi. Jakarta: Salemba Empat. 
Halim, Abdul dan M. Syam Kusufi. 2013. Akuntansi Sektor Publik: Akuntansi Keuangan Daerah. Jakarta: Salemba Empat.

Ikasari, Putri. 2015. Pengaruh Dana Alokasi Umum, Dana Alokasi Khusus dan Belanja Modal terhadap Tingkat Kemandirian Keuangan Daerah. Skripsi. Universitas PGRI Yogyakarta. Yogyakarta.

Kuncoro, Murajad. 2010. Dasar-dasar Ekonomika Pembangunan. Edisi kelima. Yogyakarta: UPP STIM YKPN Yogyakarta.

Marizka, Reza. 2013. Pengaruh Pendapatan Asli Daerah, Dana Bagi Hasil, Dana Alokasi Umum dan Dana Alokasi Khusus terhadap Tingkat Kemandirian Keuangan Daerah Kabupaten dan Kota di Sumatera Barat. Skripsi. Universitas Negeri Padang.

Muliana. 2009. Pengaruh Rasio Pendapatan Asli Daerah (PAD), Dana Alokasi Umum (DAU), dan Dana Alokasi Khusus (DAK) terhadap Tingkat Kemandirian Keuangan Daerah pada Pemerintahan Kabupaten / Kota di Sumatera Utara. Skripsi USU. Medan.

Peraturan Daerah Kabupaten Sumbawa Nomor 4 Tahun 2011 tentang Anggaran Pendapatan dan Belanja Daerah Tahun Anggaran 2012.

Peraturan Daerah Kabupaten Sumbawa Nomor 17 Tahun 2013 tentang Anggaran Pendapatan dan Belanja Daerah Tahun Anggaran 2013.

Peraturan Pemerintah Nomor 104 Tahun 2000 tentang Dana Perimbangan.

Sekaran, Uma. 2011. Research Methods for business, edisi I and 2. Jakarta: Salemba Empat.

Sidik, Machfud. 2002. Perimbangan Keuangan Pusat dan Daerah sebagai Pelaksanaan Desentralisasi Fiskal. Makalah disampaikan dalam Seminar Setahun Implementasi Kebijaksanaan Otonomi Daerah di Indonesia. Yogyakarta, 13 Maret 2002.

2004. Bunga Rampai Desentralisasi Fiskal, Direktorat Jenderal Perimbangan Keuangan Pusat dan Daerah. Jakarta. 
Sudiyarti, Nining. 2013. Analisis Kemandirian Keuangan Daerah Kabupaten Sumbawa periode 2005-2011. Jurnal Ekonomi dan Bisnis, Jilid 1 Nomor 2, April 2013.

Sugiyono. 2011. Metode Penelitian Kuantitatif, Kualitatif dan R\&D. Bandung: Alfabeta.

----------. 2017. Metode Penelitian Kuantitatif, Kualitatif dan R\&D. Bandung: Alfabeta.

Sumbawakab.bps.go.id.

Suparmoko, M. 2002. Ekonomi Publik, Untuk Keuangan dan Pembangunan Daerah. Yogyakarta: Andi.

Undang-Undang Republik Indonesia Nomor 32 Tahun 2004 tentang Pemerintahan Daerah.

Undang-Undang Republik Indonesia Nomor 33 Tahun 2004 tentang Perimbangan Keuangan antara Pemerintah Pusat dan Pemerintah Daerah.

Warsito. 2001.Pendapatan Asli Daerah. Jakarta : PT. Rajawali Grafindo Persada.

Yani, Ahmad. 2002. Hubungan Keuangan Antara Pemerintah Pusat dan Daerah di Indonesia. Jakarta: Grafindo. . 2004. Hubungan Keuangan Antara Pemerintah Pusat dan Daerah. Jakarta: Grafindo.

Yulianto, Andri. 2018. Analisis Pengaruh Pendapatan Asli Daerah, Dana Alokasi Umum, Dana Alokasi Khusus dan Belanja Modal terhadap Tingkat Kemandirian Keuangan Daerah. Skripsi. Universitas Muhammadiyah Surakarta.

Warsito. 2001.Pendapatan Asli Daerah. Jakarta : PT. Rajawali Grafindo Persada. 